\title{
Universities and Regional Development in Central and Eastern Europe - Far from being obvious
}

\author{
Zsófia Veréb Miskolczi - Katalin Erdős \\ 1 University of Pécs, Faculty of Business and Economics \\ 2 University of Pécs, Faculty of Business and Economics; MTA-PTE Innovation and \\ Economic Growth Research Group; RIERC - Regional Innovation and Entrepre- \\ neurship Research Centre
}

\section{THE AIMS OF THE PAPER}

The increased interest of researchers and policy makers towards higher educational institutions as innovation actors is partly due to internationally well-known examples of the Silicon Valley, Route 128, the Research Triangle or Oxbridge area, just to mention a few. However, the replication of these success stories in other regions that have historically different development paths, institutional, economic and social contexts is not an easy task. The study aims to introduce the most important findings on the role of universities in regional development in peripheral Central and Eastern European countries. A special emphasis is given to those factors that can impede universities' successful regional developmental role.

\section{METHODOLOGY}

The paper is based on literature survey.

\section{MOST IMPORTANT RESULTS}

The existing empirical evidences suggest that the Central and Eastern European countries face many challenges if they wish to see their universities contributing to the development of their surroundings. The socialist heritage, the low absorptive capacity of companies, the mismatch between the research interest of universities and industry, and the individual motivations all has to be analysed and understood before developing policies and measures.

\section{RECOMMENDATIONS}

The unique historical development path of science, economy and society in Central and Eastern Europe has to be considered at the design and implementation of innovation policies. Failing to do so and simply trying to transfer elements and solutions of high-tech regions is unlikely to lead to success.

Keywords: regional development, university, innovation, Triple Helix, Central and Eastern Europe

Acknowledgements: This publication/research has been supported by the European Union and Hungary and co-financed by the European Social Fund through the project EFOP-3.6.2-16-2017-00017, titled "Sustainable, intelligent and inclusive regional and city models".

DOI: 10.15170/MM.2020.54.KSZ.I.05 


\section{INTRODUCTION}

In the $20^{\text {th }}$ century the importance of knowledge assets has increased and knowledge-intensive industries became the primary boosters of the economy (OECD 1996, David \& Foray 2002). As a result, universities' role became into the focus (Cooke 2001, Olssen \& Peters 2005, Arbo \& Benneworth 2007, OECD 2007). The literature divides the local economic impact of universities into two categories. One the one hand, the spending effect measures the local economic impact of universities' expenditures and the multiplication of those. On the other hand, the knowledge impact analyses universities as producers of knowledge and the benefits of the knowledge spillovers in the region (Varga 2004, Florax 1992). The research on the spending effect became very popular since the 1970 s, especially in the USA, where almost every university assessed its local economic impact in order to justify the proper use of state funding (Drucker \& Goldstein 2007) ${ }^{1}$. However, it has to be noted that the calculations were methodologically heterogeneous and sometimes questionable (Siegfried et al. 2007, Garrido-Yserte \& Gallo-Rivera 2010).

The importance of knowledge impact and spillovers was gradually appreciated over the past decades. Universities got under double pressure in order to enhance knowledge utilization and knowledge transfer activities. There was an internal force represented by the declining state funding on the one hand, and well-known international success stories, e.g. that of the Silicon-Valley meant an external pressure on the other.

The regional innovation policies focussed on the well-performing regions and tried to replicate those 'best practices' in other regions (Tödtling \& Trippl 2005, Eder 2018). However, many studies (Varga 2000, Goldstein \& Renault 2004, Goldstein \& Drucker 2006) and empirical failures proved that the role of universities is highly contextual, influenced by economic and social factors. On the example of Hungary Bajmócy and Lukovics (2009) demonstrated that the presence of a university itself does not induce faster economic growth in a region. The role and impact of higher education institutions in their regions are influenced by internal and external factors, e.g. the economic, legal and social environment. As a result, more differentiated development policies (Tödtling \& Trippl 2005) became popular that determined the role of universities distinguished based on the characteristics of the regions (Boucher et al. 2003).

This paper analyses the regional development impact of universities in peripheral Central and Eastern European ${ }^{2}$ (CEE) regions. Based on the existing literature, the paper focuses on the following research questions: (1) What is the role of universities in regional development? (2) What are the obstacles peripheral regions' universities face during their third mission? (3) What further specificities can influence the regional development contribution of universities in the CEE peripheries?

A special emphasis is given to the expectations toward the contribution of universities and the potential hindering factors of those in the given social and political context. The paper is structured as follows. The second part introduces the regional development impact of universities in general. The third part discusses the role of universities in peripheral regions, while the fourth focuses specifically on the Central and Eastern European context. Summary closes the paper.

\section{UNIVERSITIES AS REGIONAL DEVELOPMENT ACTORS}

Universities underwent considerable changes in the past decades regarding their missions that now range from the traditional educational function to complex infrastructural development of a region

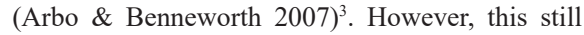
ongoing development is differentiated in space and time. There has been many - partly overlapping concepts developed on the contribution of universities to regional development (see e.g. Trippl et al. 2015).

The increased importance of knowledge resulted in an increased interest towards and pressure on universities as the generators of knowledge. The so-called first generation universities' primary mission was education, the dissemination of

\footnotetext{
1 There are also empirical works on the local economic impact of Hungarian universities by Kotosz (2013) and Kotosz et al. (2018) that provides a cross-country comparison between Hungary and France.

2 In this study Central and Eastern European countries are Bulgaria, Czech Republic, Estonia, Latvia, Lithuania, Poland, Hungary, Romania, Slovakia, and Slovenia.

3 For more details on the specific activities through which universities contribute to regional development see e.g. Lawton Smith (2007), Varga and Erdős (2019).
} 
knowledge, whereas second generation universities played an important role in the generation of knowledge through increased research activity. In the past decades the third generation or entrepreneurial university attracted attention that beyond teaching and research undertakes knowledge utilization mission as well. (Youtie \& Shapira 2008, Wissema 2009) Recently the notion of the "fourth generation" university has evolved that aims to actively shape its local economic and social environment instead of simply meeting local needs (Pawlowski 2009, Lukovics - Zuti 2014). The concept of the fourth generation universities in not fully elaborated yet, but they can play a very important role primarily in lagging regions. (Imreh-Tóth - Lukovics 2014)

The entrepreneurial university is much more open towards its environment than the previous "ivory tower" type of university and it contributes to the development of its surrounding with the other regional stakeholders (Etzkowitz 2017). This is well exemplified by the so-called Triple Helix model where the university/scientific, the business and the governmental spheres jointly determine the innovation capacity of the region through their inter-relatedness and dynamic interactions that induce change. Efficient co-operation is supported by the overlaps among the spheres. (Leydesdorff \& Etzkowitz 1996)

The Triple Helix model also lays down a development path to governments that also had an impact on the innovation policy of the European Union (Lukovics - Zuti 2014). There are extensions of the Triple Helix model. The Quadruple-Helix model also adds civil sphere and local society, whereas the Quintuple-Helix also includes the environmental sphere. (Carayannis et al. 2012, Vas 2012)

\section{THE ROLE OF UNIVERSITIES IN PERIPHERAL REGIONS}

The increased interest towards the role of universities in the development of peripheral regions has many reasons. First, the increased importance of knowledge in the knowledge-based economy put knowledge and innovation into the centre of economic development. The higher education institutions as the most important ones in the generation of knowledge, especially in regions that are peripheral in economic sense with low industrial R\&D activity, play a very important role in these. Second, codified knowledge in form of patents and licences plays a more important role in high-tech regions with large agglomerations (Varga 2004). While peripheral regions that are typically dominated by traditional industries are able to innovate, usually the development and measurement of this requires different approaches and methods (Eder 2018). Third, theories, e.g. the Triple-Helix model of innovation (Etzkowitz \& Leydesdorff 2000) or the concept of regional innovation systems (Freeman 1995), that emphasize the importance of cooperation of key actors (among them universities) in the regional development further strengthened this process. Fourth, the regional economic development role of universities can be better demonstrated in small, economically weak regions where the agglomeration and other effects do not suppress these impacts (Goldstein \& Drucker 2006).

As a result, there has been a huge pressure on universities in peripheral regions in order to make them contribute to the economic and social development of the region (Karlsen et al. 2017). This expectation is complex and encompasses the entire functioning and all missions of universities. They are required to adjust education to the local needs, while generate knowledge with practical use and the same time their regional embedding should spur economic development in the region (Kwiek 2012a). As it is demonstrated by case studies as well, these targets were in many instances excessive, overwhelmingly optimistic and hard to achieve in practice (Gunasekara 2006, Gál - Ptáček 2011).

Karlsen and colleagues (2017) highlight that meeting the new expectations requires fundamental modification of universities' attitude. They also argue that so far universities primarily had to meet standards that were set outside of the region. The principles of their functioning and their funding conditions are determined by the national regulation. This creates a fundamental financial dependence, especially in peripheral regions, where universities cannot rely on revenue from industrial cooperation or patenting and licensing. Additionally, in order to meet academic standards they try to build a scientifically highly qualified institution that makes them having to compete with the international academic sphere (Karlsen et al. 2017).

Teaching is the first and most important mission of universities. Empirical studies have shown that it is the most relevant activity of peripheral regions' universities in order to promote economic development (Vallance et al. 2018, Karlsen et al. 2017). Through their educational activity universities contribute to the development of human resources in the region that is a precondition of the evolution of innovative companies. In order to promote regional development, universities are required to tailor their educational structure to the regional needs, but this 
effort is not rewarded in revenue terms. As Kwiek (2012b) has demonstrated on Poland's example, this is only different in case of private universities whose primary revenue is the tuition fee and enrol students from the local region, thus the supply is adjusted to their demand. However, universities are also competing outside the region in order to attract the best students and faculty and the alignment of these needs is not always possible (Kempton 2015).

Economically underdeveloped areas can be characterized by low level of innovative activity due to the poor industrial R\&D demand and activity, to the disconnectedness of the actors, respectively to the low regional embedding of the R\&D infrastructure (Muscio et al. 2015). Though there is a desperate need for innovation investments in these regions, the low absorptive capacity impedes the utilization of subsidies (Oughton et al. 2002). The establishment of university-industry relations is more difficult in these regions due to low number of companies and their low absorptive capacity (Karlsen et al. 2017, Cohen \& Levinthal 1990). Further obstacle of university-industry interactions is the mismatch between the research areas of the university and the interests of the local industrial ecosystem (Brown 2016). On the other hand, if universities only strive to meet local demand in regions where there are no internationally competitive companies they may miss the chance to become world-class institutions (Kempton 2015).

\section{THE REGIONAL ECONOMIC DEVELOPMENT IMPACT OF UNIVERSITIES IN CENTRAL AND EASTERN EUROPE'S PER-
IPHERIES}

Most of the challenges of the peripheral universities in the Central and Eastern Europe are similar to those of their Western European counterparts, however, there is a considerable difference between the higher educational institutions of the two areas. This can be owed to the socialist impact, respectively to the differing economic and social environment. The former Soviet Union has been characterized by the statist model of societal organization where the government dominated and regulated the interaction of the spheres in the Triple Helix, universities were responsible for teaching and were distant from industry (Etzkowitz 2008). Although the CEE universities underwent significant changes in the past decades, the more rapid transformation of the Western European universities maintained the permanent gap between the two. CEE universities lag far behind not only the world-class institutions, but also their Western European counterparts considering rankings. In 2018 there were only three CEE institutions among the top 500 in The Times Higher Education ranking. We do not find any CEE institution in the top 100 European universities. Though this is partly due to the measures used for the ranking and is influenced by country-specific factors, the differences clearly highlight the limited higher educational capacity that is determined by the permanent underfunding and emigration of intellectual capital (Boyadjieva 2017).

The R\&D expenditure to GDP ratio were relatively high in the CEE countries, though these were primarily state-funded. Until the 1990s the primary mission of universities was teaching, while research and development activities were primarily carried out by academies of sciences, and applied research was undertaken by industrial research units. (Gál - Ptáček 2011) Teaching remained the primary mission of universities after the system change as well (Gál - Ptáček 2011), but the importance of the R\&D activities has increased as research units of the academies of sciences were integrated into large universities (Jarohnovich \& Avotins 2013), resulting in the dominance of them in research and development (Radosevic \& Lepori 2009). As Karo and Looga (2016) highlight, industrial $R \& D$ expenditures in these countries are usually very low in absolute and in percentage terms as well. Slovenia is a notable exception where the private sector is historically active in $R \& D$ funding, especially in the applied field (Karo \& Looga 2016). The R\&D cooperation between the private and the public sector is strong, however, primarily between other public research organizations and the industrial actors while universities play a minor role (Koschatzky 2002).

Despite the shared socialist past there are significant differences among the CEE countries' innovation and higher education systems. Regional innovation strategies initially targeted the fulfilment of EU accession conditions (Karo \& Looga 2016), later on the maximization of subsidies (Jarohnovich \& Avotins 2013). After the system change the countries followed different path considering their R\&D policy and innovation systems, respectively the role of universities in regional development (Lepori et al. 2009, Boyadjieva 2017, Dobbins \& Kwiek 2017). However, some features are similar across these countries.

University-industry interactions and knowledge transfer remained weak in the CEE regions after 2000 for many reasons (Inzelt 2004). On the 
one hand, the university sphere was not interested in industrial cooperation, its focus was on basic research (Gál - Ptáček 2011). On the other hand, the industrial sphere's low absorptive capacity made it an unprepared actor for cooperation (Inzelt 2004, Lengyel - Cadil 2009). The Central and Eastern European companies consider cooperation with universities less important - even in European comparison (Kwiek 2012a). Local companies are often unaware whether and how they could establish a connection with the university as an institution, even though they are more frequently connected to researchers (Imreh-Tóth - Lukovics 2014, Kwiek 2012a). University-industry interactions are characterized by the importance of personal relations (Vallance et al. 2018, Kwiek 2012a).

Since company R\&D activity is usually low in these regions, universities can hardly substitute central government funding with local revenue sources. The opening of universities towards knowledge utilization at the beginning of the 2000s was based on the imitation of Western-European examples, with very limited success (Gál - Ptáček 2011), the contribution of universities to industrial innovation remained extremely narrow (Prokop et al. 2018). Multinational companies often have only premises in these regions, their R\&D activity is located elsewhere, and their connections to local companies are rather ad hoc (Prudky \& Smidova 2019). Universities can enhance the attraction of multinational companies, but primarily because of their ability to emit cheap and qualified labour force in the region, the educational or R\&D co-operations evolve slowly and only due to governmental incentives. (Lengyel et al. 2006)

Though researchers show more interest in knowledge transfer recently, universities are not welcomed actors in these transactions - partly - due to their highly bureaucratic operation (Novotny 2014, Vallance et al. 2018). Based on the ERAWATCH country reports Serbanica and Dragan (2012) argue that the most important hindrances are institutional regulation, human resources, deficiencies of the research infrastructure and $\mathrm{R} \& \mathrm{D}$ funding. University-industry interactions in many instances are more about providing services than utilizing research results (Vallance et al. 2018).

Motivations and characteristics of Central and Eastern European academic entrepreneurs and spinoffs are often different from American and Western Europeans. Usually they are based on personal motivations or financial constrains (Erdős - Varga 2013, Tchalakov et al. 2010). This view is supported by Novotny (2014) who found that the most important trigger for entrepreneurship was resource constrain followed by research related benefits, need for independence and performance.

Karlsen and colleagues (2017) analysed the regional development role of universities based on the relationship between regional governance and universities in two Czech and two Norwegian regions. They argue that the attitude of the regional leadership strongly influences the role of universities. However, they also highlight, that primarily through its educational activity a university can be a very important local development actor in areas without the support of the regional leadership, despite the low level of absorptive capacity of local companies (Karlsen et al. 2017). In order to achieve real success it is important that the key actors of the region recognize the importance of the issue and determine long-run common goals (Kempton 2015) with appropriate and stable financial support (Keerberg 2018).

Vallace and colleagues (2018) observed many types of university-industry collaborations were in two CEE regions. The stakeholders highlighted the role of higher education institutions in supplying qualified labour. Higher education institutions highlighted joint R\&D activity, whereas companies mentioned problem solving as the most important form of cooperation. Stakeholders believed that the largest obstacle of cooperation with universities was the behaviour of those. Vallance and colleagues (2018) argued that this can be owed to the insufficient financial incentives for university-industry collaboration provided by the government on the one hand (despite the considerable achievements of Poland in this respect). On the other hand, the institutions achieved a high level of autonomy and internal democracy after the collapse of the socialism, thus have institutional set-ups that they hardly wish to change (Vallance et al. 2018).

\section{SUMMARY}

The regional role of universities goes beyond their pure economic impact, they are important in political, cultural, demographic and infrastructural sense as well (Florax 1992) that can be especially pronounced in peripheral regions. This paper provided a brief insight into the role of universities in peripheral Central and Eastern European regions. While the most important research question in centrally located large universities is how they are able to turn their countries into the leader of the world economy, in case of the peripheral Central and Eastern European regions the question is rather how they are able to contribute to the development 
of the region by targeting catching-up. Karlsen and colleagues (2017) argue that the theory on the role of universities in regional development simply has been transferred from the highly developed regions to the peripheral ones without considering the specificities of those. In the absence of other economic, innovation and competitive factors of the region this put an excessive pressure on higher education institutions, that cannot be expected to make a miracle themselves (Kwiek 2012b).

Universities had a strong autonomy in the past that primarily adjusted their activity to the national and international expectations, while regional leaders today expect them to respond to the educational and research needs of the region, respectively strengthen the entrepreneurial activity of that, despite the low absorptive capacity and weak feedbacks. While political and economic decision makers of peripheral regions look at universities as primary sources of innovation, universities cannot meet this expectation and knowledge generated by them cannot be transferred due to the deficiencies of the regional ecosystem, primarily to the low absorptive capacity, diverging research areas and low level of venture capital (Brown 2016).

Besides the obvious gap between the more developed regions of the EU and the Central and Eastern European regions, there are differences between the Central and Eastern European countries, regions and universities as well. The challenges they face are in many instance similar to those of universities in other peripheral regions.

In the lagging regions of Central and Eastern Europe, the currently most important contribution of universities to regional development is education, but they also put an emphasis on research activities, respectively there is a clearly observable effort towards becoming entrepreneurial universities. However, due to the low level of local absorptive capacity this is stronger present in aims and development plans than in reality.

Instead of imitating developed benchmarks, customized solutions are needed in order to achieve the best outcome in case of the higher education institutions of Central and Eastern European regions. This cannot done by universities alone, the cooperation of different actors and different levels is needed. 


\section{REFERENCES}

Arbo, P. and Benneworth, P. (2007), 'Understanding the Regional Contribution of Higher Education Institutions: A Literature Review", OECD Education Working Papers, No. 9. OECD Publishing (NJ1). DOI: $10.1787 / 161208155312$

Bajmócy, Z. and Lukovics, M. (2009), "Subregional Economic and Innovation Contrubution of Hungarian Universities", in: Bajmócy, Z. and Lengyel, I. (eds.) Regional Competitiveness, Innovation and Environment. Szeged: JATE Press, 142-161. DOI: 10.1787/161208155312

Boucher, G., Conway, C. and Van Der Meer, E. (2003), "Tiers of engagement by universities in their region's development", Regional Studies, 37(9), 887-897. DOI: 10.1080/0034340032000143896

Boyadjieva, P. (2017), "Invisible higher education: Higher education institutions from Central and Eastern Europe in global rankings", European Educational Research Journal, 16(5), 529-546. DOI: $10.1177 / 1474904116681016$

Brown, R. (2016), 'Mission impossible? Entrepreneurial universities and peripheral regional innovation systems", Industry and Innovation, 23(2), 189-205. DOI: 10.1080/13662716.2016.1145575

Carayannis, E. G., Barth, T. D. and Campbell, D. F. J (2012), 'The Quintuple Helix innovation model: global warming as a challenge and driver for innovation", Journal of Innovation and Entrepreneurship. 1(1) 1-12. DOI:10.1186/21925372-1-2

Cohen, W. M. and Levinthal, D. A. (1990), ”Absorptive capacity: A new perspective on learning and innovation", Administrative Science Quarterly, 128-152. DOI: $10.1016 / \mathrm{b} 978-0-7506-7223$ 8.50005-8

Cooke, P. (2001), "Regional innovation systems, clusters, and the knowledge economy", Industrial and Corporate Change, 10(4), 945-974. DOI: $10.1093 /$ icc/10.4.945

David, P. A. and Foray, D. (2002), "An introduction to the economy of the knowledge society", International Social Science Journal, 54(171), 9-23. DOI: $10.1111 / 1468-2451.00355$

Dobbins, M. and Kwiek, M. (2017), 'Europeanisation and globalisation in higher education in Central and Eastern Europe: 25 years of changes revisited (1990-2015)." European Educational Research Journal, 16(5), 519-528. DOI: $10.1177 / 1474904117728132$

Drucker, J. and Goldstein, H. (2007), ”Assessing the regional economic development impacts of universities: A review of current approaches", International Regional Science Review, 30(1), 20-46. DOI: $10.1177 / 0160017606296731$

Eder, J. (2018), 'Innovation in the periphery: A critical survey and research agenda", International
Regional Science Review, 42(2), 119-146. DOI: $10.1177 / 0160017618764279$

Erdős, K. and Varga, A. (2013), "Academic entrepreneurs in post-socialist Central European countries: evidence from the Hungarian biotechnology sector", in Capello, R., Olechnicka, A. and Gorzelak, G. (eds.): Universities, Cities and Regions: Loci for knowledge and innovation creation. London and New York: Routledge, 229-245.

Etzkowitz, H. (2008), The Triple Helix: University-Industry-Government Innovation in Action. London and New York: Routledge. DOI: 10.4324/9780203929605

Etzkowitz, H. (2017), "Innovation Lodestar: The entrepreneurial university in a stellar knowledge firmament", Technological Forecasting and Social Change, 123, 122-129. DOI: 10.1016/j. techfore.2016.04.026

Etzkowitz, H. and Leydesdorff, L. (2000), The dynamics of innovation: from National Systems and "Mode 2" to a Triple Helix of university-industry-government relations", Research Policy, 29(2), 109-123. DOI: 10.1016/s00487333(99)00055-4

Freeman, C. (1995), "The 'National System of Innovation'in historical perspective", Cambridge Journal of Economics, 19(1), 5-24. DOI: 10.1093/oxfordjournals.cje.a035309

Florax, R. (1992), The University: a regional booster? Economic impacts of academic kowledge infrastructure. Hants (UK): Avebury

Gál, Z. and Ptaček, P. (2011), "The role of mid-range universities in knowledge transfer in non-metropolitan regions in Central Eastern Europe", European Planning Studies, 19(9), 1669-1690. DOI: 10.1080/09654313.2011.586186

Garrido-Yserte, R. and Gallo-Rivera, M. T. (2010), "The impact of the university upon local economy: three methods to estimate demand-side effects", The Annals of Regional Science, 44(1), 39-67. DOI: 10.1007/s00168-008-0243-x

Goldstein, H. and Renault, C. (2004), "Contributions of universities to regional economic development: A quasi-experimental approach", Regional studies, 38(7), 733-746. DOI: 10.1080/0034340042000265232

Goldstein, H. and Drucker, J. (2006), "The economic development impacts of universities on regions: Do size and distance matter?", Economic development quarterly, 20(1), 22-43. DOI: $10.1177 / 0891242405283387$

Gunasekara, C. (2006), "Universities and associative regional governance: Australian evidence in non-core metropolitan regions", Regional Studies, 40(7), 727-741. DOI: 10.1080/00343400600959355

Imreh-Tóth M., Lukovics M. (2014), „Egyetem- 
központú vállalkozásfejlesztés elmaradott térségekben: negyedik generációs egyetemi funkciók?" Marketing \& Menedzsment, 48(2), 43-56. Available: https://journals.lib.pte.hu/ index.php/mm/article/view/993 (Accessed: 24 January 2020)

Inzelt, A. (2004), „Az egyetemek és a vállalkozások kapcsolata az átmenet idején", Közgazdasági Szemle, 51(9), 870-890.

Jarohnovich, N. and Avotins, V. (2013), "The Changing Role of the Entrepreneurial University in Developing Countries: The Case of Latvia", Journal of Higher Education Theory and Practice. 13(2), 121-148

Karlsen, J., Beseda, J., Šima, K. and Zyzak, B. (2017), "Outsiders or Leaders? The Role of Higher Education Institutions in the Development of Peripheral Regions", Higher Education Policy, 30(4), 463-479. DOI: 10.1057/s41307017-0065-5

Karo, E. and Looga, L. (2016), "Understanding institutional changes in economic restructuring and innovation policies in Slovenia and Estonia", Journal of International Relations and Development, 19(4), 500-533. DOI: 10.1057/jird.2014.23

Keerberg, A. (2018), "Higher education institutions at the periphery of the periphery: Creating sustainable economic development in Estonia", in Benneworth, P. (ed.), Universities and Regional Economic Development, London and New York: Routledge, 127-144. DOI: 10.4324/9781315168357-9

Kempton, L. (2015), 'Delivering smart specialization in peripheral regions: the role of Universities", Regional Studies, Regional Science, 2(1), 489-496. DOI: 10.1080/21681376.2015.1085329

Koschatzky, K. (2002), "Networking and knowledge transfer between research and industry in transition countries: Empirical evidence from the Slovenian innovation system", The Journal of Technology Transfer, 27(1), 27-38. DOI: 10.1023/A:1013192402977

Kotosz, B. (2013), "The Local Economic Impact of Higher Education Institutions in Hungary", in: Khavand, K. J. (ed.), Intellectual Capital Management. Global Perspectives on Higher Education, Science and Technology, Springer, 45-60.

Kotosz, B., Gaunard-Anderson, M. F., and Lukovics, M. (2018), "The local economic impact of universities: an international comparative analysis (France and Hungary)", in: Ateljević, J. and Budak, J. (eds.), Entrepreneurship in Post-Communist Countries: New Drivers Towards a Market Economy. Springer. Entrepreneurship in Post-Communist Countries, Springer, 115-131. DOI: 10.1007/978-3-319-75907-4 8

Kwiek, M. (2012a), 'Universities, regional development and economic competitiveness: The Polish case", in Pinheiro, R., Benneworth, P. and Jones, G. A. (eds.), Universities and Regional Development, London and New York: Routledge, 89-105.

Kwiek, M. (2012b), "Universities and knowledge production in Central Europe", European Educational Research Journal, 11(1), 111-126. DOI: 10.2304/eerj.2012.11.1.111

Lawton Smith, H. (2007), "Universities, innovation, and territorial development: A review of the evidence", Environment and Planning C: Government and Policy, 25(1), 98-114. DOI: 10.1068/ c0561.

Lengyel, B. and Cadil, V. (2009), "Innovation policy challenges in transition countries: foreign business R\&D in the Czech Republic and Hungary", Transition Studies Review, 16(1), 174-188. DOI: 10.1007/s11300-009-0046-5

Lengyel, B., Lukács, E. and Solymári, G. (2006), "A külföldi érdekeltségú vállalkozások és az egyetemek kapcsolatai Győrött, Miskolcon és Szegeden”, Tér és Társadalom, 20(4), 127-144. DOI: $10.17649 /$ tet.20.4.1082

Lepori, B., Masso, J., Jabłecka, J., Sima, K. and Ukrainski, K. (2009), "Comparing the organization of public research funding in central and eastern European countries", Science and Public Policy, 36(9), 667-681. DOI: 10.3152/030234209x479494

Leydesdorff, L. and Etzkowitz, H. (1996), "Emergence of a triple helix of university-industry-government relations", Science and Public Policy, 23(5), 279-286

Lukovics M. and Zuti B. (2014), ,Egyetemek a régiók versenyképességének javításáért: „,negyedik generációs" egyetemek?", Tér és Társadalom, 28(4), 77-96. DOI: 10.17649/tet.28.4.2587

Muscio, A., Reid, A. and Rivera Leon, L. (2015), "An empirical test of the regional innovation paradox: can smart specialisation overcome the paradox in Central and Eastern Europe?", Journal of Economic Policy Reform, 18(2), 153-171. DOI: $10.1080 / 17487870.2015 .1013545$

Novotny, Á. (2014), „Siker és motiváció a magyar vállalkozó-kutatók körében", Competitio, 13(1), 75-87. DOI: $10.21845 / \mathrm{comp} / 2014 / 1 / 5$

OECD (1996), The Knowledge-Based Economy. Paris: OECD.

OECD (2007), Higher Education and Regions: Globally Competitive, Locally Engaged, Paris: OECD

Olssen, M. and Peters, M.A. (2005), "Neoliberalism, higher education and the knowledge economy: From the free market to knowledge capitalism", Journal of Education Policy, 20(3), 313-345. DOI: $10.1080 / 02680930500108718$

Oughton, C., Landabaso, M. and Morgan, K. (2002), "The regional innovation paradox: innovation policy and industrial policy", The Journal of Technology Transfer, 27(1), 97-110. DOI: 


\subsection{3/A:1013104805703}

Pawłowski, K. (2009), The 'fourth generation university' as a creator of the local and regional development. Higher Education in Europe, 34(1), 51-64. DOI: 10.1080/03797720902747017

Prokop, V., Odei, S. A. and Stejskal, J. (2018), "Relationship of University-Industry Cooperation and Innovative Activities", Marketing \& Menedzsment, 52 2, 85-95.

Prudký, L. and Šmídová, M. (2019), "Vysočina region: from a remote rural region straight into the virtual world", in Benneworth, P. (ed.), Universities and Regional Economic Development, London and New York: Routledge, 92-109. DOI: 10.4324/9781315168357-7

Radosevic, S. and Lepori, B. (2009), "Public research funding systems in central and eastern Europe: between excellence and relevance: introduction to special section", Science and Public Policy, 36(9), 659-666. DOI: $10.3152 / 030234209 \times 475236$

Siegfried, J. J., Sanderson, A. R. and McHenry, P. (2007), "The economic impact of colleges and universities", Economics of Education Review, 26(5), 546-558. DOI: 10.1016/j.econedurev.2006.07.010

Şerbănică, C. and Drăgan, G. (2012), "University-industry cooperation in Central and Eastern Europe: A common past, a different future?" Centre for European Studies (CES) Working Papers, 4(4).

Tchalakov, I., Mitev, T. and Petrov, V. (2010), "The academic spin-offs as an engine of economic transition in Eastern Europe. A path-dependent approach", Minerva, 48(2), 189-217. DOI: 10.1007/s11024-010-9149-8

Tödtling, F. and Trippl, M. (2005), "One size fits all?: Towards a differentiated regional innovation policy approach", Research Policy, 34(8), 1203 1219. DOI: $10.1016 /$ j.respol.2005.01.018
Trippl, M., Sinozic, T. and Lawton Smith, H. (2015), "The role of universitiesinregionaldevelopment: conceptualmodels and policy institutionsinthe UK, Sweden and Austria", European Planning Studies, 23(9), 1722-1740. DOI: 10.1080/09654313.2015.1052782

Vallance, P., Blažek, J., Edwards, J. and Květoň, V. (2018), "Smart specialisation in regions with less-developed research and innovation systems: A changing role for universities?", Environment and Planning C: Politics and Space, 36(2), 219238. DOI: $10.1177 / 2399654417705137$

Varga, A. (2000), 'Local academic knowledge transfers and the concentration of economic activity", Journal of Regional Science, 40(2), 289-309. DOI: $10.1111 / 0022-4146.00175$

Varga, A. (2004), „Az egyetemi kutatások regionális gazdasági hatásai a nemzetközi szakirodalom tükrében”, Közgazdasági Szemle, 51(3), 259275. DOI: 10.1111/0022-4146.00175

Varga, A., and Erdős, K. (eds.), (2019), Handbook of Universities and Regional Development. Cheltenham: Edward Elgar Publishing. DOI: $10.4337 / 9781784715717$

Vas Zs. (2012), „Tudásalapú gazdaság és társadalom kiteljesedése: A Triple Helix továbbgondolása-a Quadruple és Quintuple Helix", in: Rechnitzer J. and Rácz Sz. (eds.): Dialógus a regionális tudományról. Győr-Pécs: Széchenyi István Egyetem Regionális- és Gazdaságtudományi Doktori Iskola - Magyar Regionális Tudományi Társaság, 198-206.

Wissema, J. G. (2009), Towards the third generation university: Managing the university in transition. Edward Elgar Publishing. DOI: $10.4337 / 9781848446182$

Youtie, J., and Shapira, P. (2008), "Building an innovation hub: A case study of the transformation of university roles in regional technological and economic development", Research Policy, 37(8), 1188-1204. DOI: 10.1016/j.respol.2008.04.012

Zsófia Veréb Miskolczi, Research Assistant vereb-miskolczi.zsofia@ktk.pte.hu University of Pécs Faculty of Business and Economics

Katalin Erdős, $\mathrm{PhD}$, Associate Professor erdosk@ktk.pte.hu University of Pécs

Faculty of Business and Economics MTA-PTE Innovation and Economic Growth Research Group RIERC - Regional Innovation and Entrepreneurship Research Centre 